\author{
Marek MIZERÁK ${ }^{1}$, Peter TREBUŇA² ${ }^{2}$ Jozef TROJAN², Ján KOPEC ${ }^{4}$ \\ Supervisor: Jaroslava KÁDÁROVÁ ${ }^{5}$ \\ DOI: https://doi.org/10.53052/9788366249844.13
}

\title{
Testbed Jako rozWiązanie dla Przemyseu 4.0
}

\begin{abstract}
Streszczenie: Ze względu na konkurencję, rentowność i presję na niskie ceny, firmy przemysłowe muszą stale wprowadzać innowacje i ulepszać swoje produkty, wydajność produkcji i logistykę. Często firmy nie mogą sobie pozwolić na próby znalezienia najlepszego rozwiązania, ponieważ produkcja musi płynąć w sposób ciągły. Firmom często brakuje informacji potrzebnych do podejmowania właściwych decyzji, więc każda zła decyzja może być dla nich bardzo kosztowna. TestBed przynosi rozwiązanie w postaci unikalnego miejsca pracy. W tym artykule opisano różne możliwości koncepcji platformy testowej, która pomaga firmom produkcyjnym rozwiązywać ich problemy.
\end{abstract}

Słowa kluczowe: stanowisko testowe, fabryka cyfrowa, cyfryzacja, bliźniak cyfrowy

\section{TESTBED AS A SOLUTION OF INDUSTRY 4.0}

Summary: Due to competition, profitability and pressure for low prices, industrial companies must constantly innovate and improve their products, production efficiency and logistics. Many times, companies cannot afford to make attempts to find the best solution, as production must flow continuously. Businesses often lack the information they need to make the right decisions, so any wrong decision can be very costly for them. TestBed brings a solution in the form of a unique workplace. This article describes the various abilities of the testbed concept which helps manufacturing companies solve their problems.

Keywords: testbed, digital factory, digitization, digital twin

\footnotetext{
${ }^{1}$ Technical University of Kosice, Faculty of Mechanical Engineering, Department of Industrial and Digital Engineering; marek.mizerak@tuke.sk

${ }^{2}$ Technical University of Kosice, Faculty of Mechanical Engineering, Department of Industrial and Digital Engineering; peter.trebuna@tuke.sk

${ }^{3}$ Technical University of Kosice, Faculty of Mechanical Engineering, Department of Industrial and Digital Engineering; jozef.trojan@tuke.sk

${ }^{4}$ Technical University of Kosice, Faculty of Mechanical Engineering, Department of Industrial and Digital Engineering; jan.kopec@tuke.sk

5 prof. Ing. PhD, Technical University of Kosice, Faculty of Mechanical Engineering,

Department of Industrial and Digital Engineering; jaroslava.kadarova@tuke.sk
} 


\section{Introduction}

In many areas of life, we use digitization without realizing it. We read e-books, walk around the museum from the comfort of home, study in digital libraries. In addition to business innovation, digitization is one of the most important business trends for the future of the economy. Companies need to keep up with this time, developing digital strategies and focusing on key success factors for the digital transformation. Digitization is affecting businesses of all sizes. On the one hand, companies need to digitize their internal processes and procedures, on the other hand, they need to develop new services and digital business models.

\section{Digital Twin}

A digital twin can be described as an intelligent digital image of a real product or process. As an innovative technology, it offers great opportunities for industry and the economy, but it also presents great challenges. Digital twins are therefore becoming increasingly important in research. These are virtual replicas of physical devices that can be called. Use data scientists and information technology professionals to run simulations before building and deploying real devices. Digital twin technology has moved beyond manufacturing, to the connecting worlds of the Internet of Things, artificial intelligence and data analytics. The more complex "things" become more and more connected with the ability to produce data, the digital equivalent gives the so-called data scientists and other IT professionals the ability to optimize deployment for maximum efficiency and create additional "what if" scenarios [2].

It is a digital representation of a physical object or system. The technology behind the digital twin has become so widespread that it includes large items such as buildings, factories, cities, and even people or processes that can have digital twins, further expanding the concept. It considers inputs from real-world data about a physical object or system and produces them as predictions of outputs or simulations of how a physical object or system will be affected by those inputs [7].

Digital twins provide manufacturers and companies with an unprecedented view of the performance of their products. The digital twin can help identify potential errors, eliminate problems that may occur in the future, and ultimately improve user satisfaction. It also helps with differentiation and product quality along with additional services $[4,6]$.

Manufacturers can see how users use their product after purchasing it, and can get a lot of information. This means that data can be used (if justified) to safely remove unwanted products, functionality or components, saving time and money. In recent years, one of the ideas of the digital twin has also appeared on the market in the form of a concept called TestBed, which is currently focused on optimizing and simulating production processes $[5,8]$.

The example shows a situation where a manufacturing company is thinking about buying machine tools with certain parameters and the TestBed concept, thanks to simulation programs, can determine various parameters that will ultimately determine the course of production. Thanks to this, the company can decide whether the device is advantageous for them $[1,3]$. 


\section{Concept of Testbed 4.0}

Due to competition, profitability and pressure for low prices, industrial companies must constantly innovate and improve their products, production efficiency and logistics. Many times, companies cannot afford to make attempts to find the best solution, as production must flow continuously. Businesses often lack the information they need to make the right decisions, so any wrong decision can be very costly for them. TestBed brings a solution in the form of a unique workplace, equipped with first-class technologies, adapted for simulation of various solution variants, their subsequent testing and finally evaluation of the most suitable, either within individual processes or comprehensively, across the entire company. It includes development and construction processes, technical preparation of production, production planning, production and logistics itself, which are interconnected in the concept of Industry 4.0. The Faculty of Mechanical Engineering of the Technical University in Košice, in cooperation with Sova Digital experts, presented the first Slovak TestBed 4.0 focused on Industry 4.0 technologies and processes. and digital transformation of industrial enterprises (Fig.1). Thanks to this, the most advantageous solution can now be designed, which is then applied in the given company. This eliminates risks, saves money, time and people[5].

TestBed 4.0 is designed for industry companies to solve their problems and challenges, top managers to look for opportunities to set an Industry 4.0 strategy, students to process projects and final theses, or specialists for the development of new products, services and solutions. It is also a suitable environment for workshops, trainings or excursions, which, thanks to specialists and top equipment, will reach a new level.

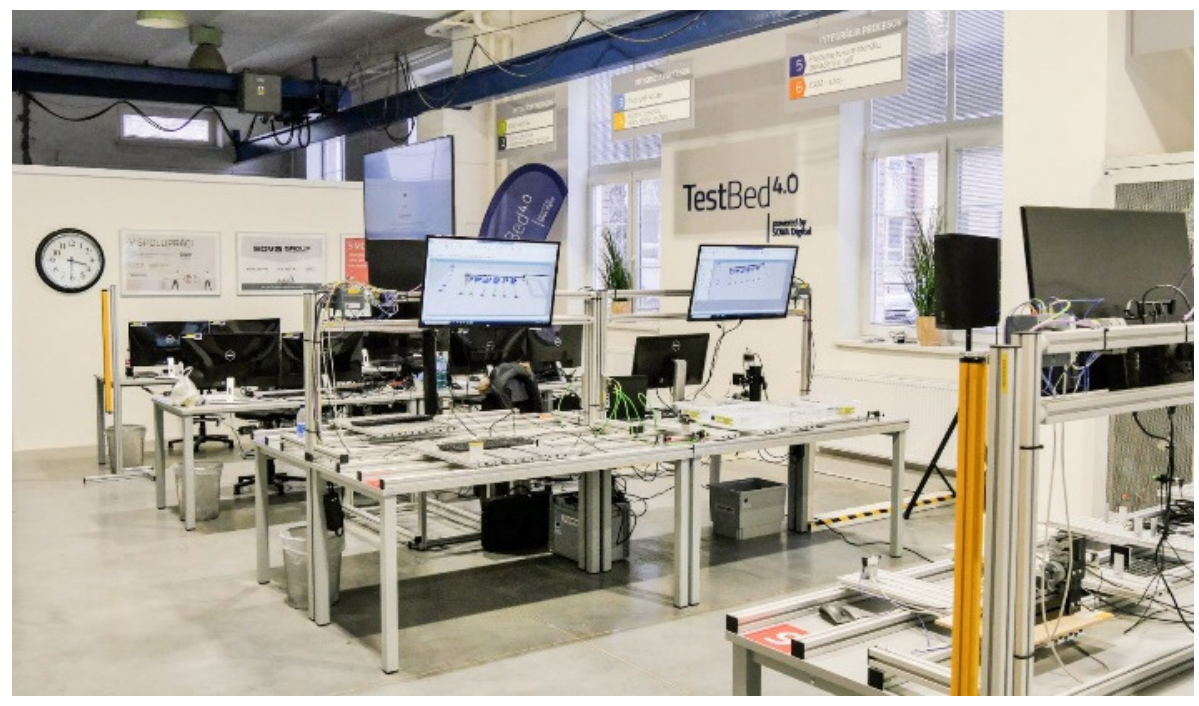

Figure 1. First TestBed in the Slovak Republic

TestBed is a benefit for the discrete manufacturing industry, small, medium and large enterprises, universities, their staff and students interested in practice. For industry, it solves the methodology, concept and procedure of the Industry 4.0 application created 
for a specific industrial enterprise, design, verification and optimization of new processes, workplaces, lines and operations for production and logistics. It solves the redesign of existing processes, operational production planning including spatial, personnel and machine constraints, design, verification and optimization of warehouses, technology and workers, warehouse management, by applying the concept of digital twins and many others, see Fig.2. TestBeds are generally used to examine system components and interactions in order to gain a more detailed view of the nature of the actual system. They are made from prototypes and parts of the actual system components and are used to provide an overview of the functioning of the system element (s). An important feature of the test bed is that it focuses only on a subset of the entire system. This is an important aspect that we want to study, improve or develop, it is an aspect implemented in the test room. TestBeds are equipped with a state-of-the-art hardware and software environment thanks to which it is possible to test individual components without having a perfect system. The test facility provides a means to improve the understanding of the functional requirements and operational behavior of the system. It is also possible to make measurements from which quantitative results about the system can be derived. It provides an integrated environment in which the interrelationships of system problem solving can be evaluated. Finally, it is able to create an environment in which design decisions can be based on both theoretical and empirical studies.

The modern TestBed concept consists of three main components: the experimental subsystem, the monitoring subsystem and the simulation and stimulation subsystem. An experimental subsystem is a collection of real-world components and prototypes that we want to model and experiment with. The monitoring subsystem consists of an interface to an experimental system for extracting raw data and a support component for comparing and analyzing the information collected. These elements can be experimented with based on different systemic stimuli, applications and configurations.

\section{Testbed 4.0 for Industry and Students}

TestBed provides services for industry that allow companies to design, test and optimize solutions tailored to their needs. In laboratory conditions, very close to reality, the workplace creates a number of versions of solutions and then chooses the most suitable one. With this step, companies avoid potential threats and are able to quickly, efficiently design, verify and implement innovations in their operations. The great advantage of TestBed 4.0 is the professional background, which covers more than 100 specialists when it is opened, from which a professional team will be assembled to solve each task, which can solve it effectively. TestBed 4.0 solves for industry methodology, concept and procedure of application Industry 4.0, created for specific industrial enterprise complex and partial integration of business processes, collection, exchange, processing and evaluation of data for industrial enterprises design, verification and optimization of new processes, workplaces, lines and facilities for production and logistics redesign of existing processes, workplaces, lines and facilities for production and logistics, operational production planning including space, personnel and machine constraints. 


\section{TestBed 4.0}

\section{solutions for}

industry
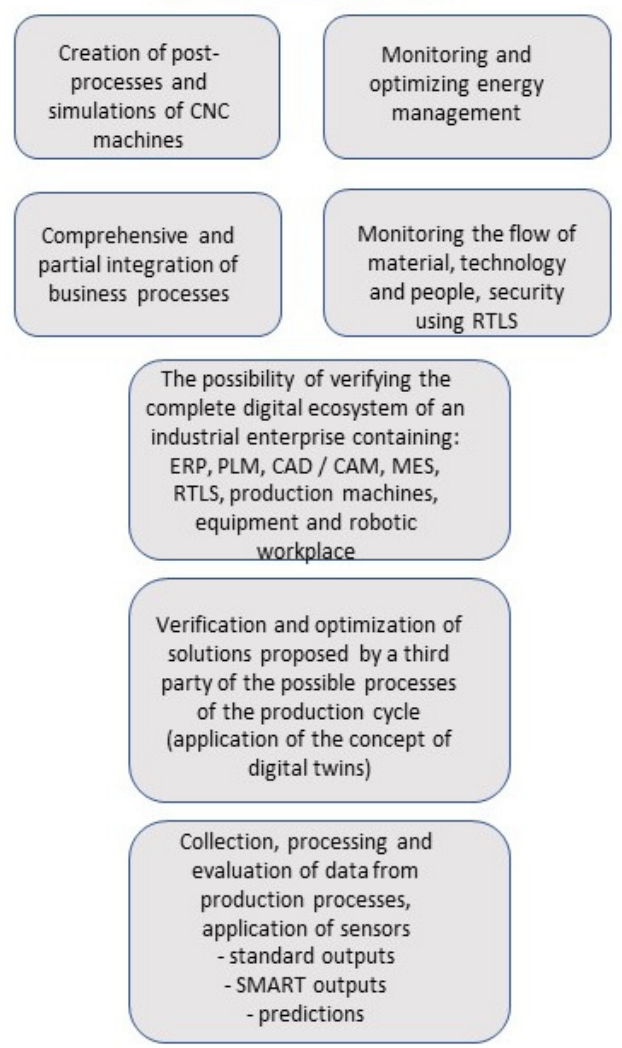

Figure 2. Benefits of TestBed 4.0 for industry

The industry desperately needs a number of experts who are interested in Industry 4.0, and this number will only increase in the future. The aim of TestBed 4.0 is to combine theoretical education with the creation of practical experience, which will increase the professional skills of graduates. TestBed 4.0 provides students with visits with an explanation and presentation of the principles and possibilities of Industry 4.0 for high school and university students, a standard educational process in the form of lectures and practical exercises, solving topics of year and final theses brought from practice, participation in solving projects for practice, participation to solve research projects university and practice projects. 


\section{Conclusion}

Digitization has become an integral part of today's world and we are direct witnesses of the industrial engineering sector taking on a new shape. Thanks to digitization, a new range of products and services have been created that make work easier for industrial companies. Although TestBed does not have a competitor in Slovakia, we can already say that this test facility will be helpful in solving the practical needs of industry in the field of Industry 4.0. By creating collaborations between industry and universities, and then involving young talented students in addressing the practical needs of the practice, Industry 4.0 will be a huge contribution to the research and development of applications. Elements of the testbed concept today are among the inseparable parts of creating a modern digital enterprise. The innovations and improvements that the testbed brings are gaining remarkable results, and further improvements are expected in the coming years.

\section{Acknowledgement}

This article was created by the implementation of the grant project APVV-17-0258

"Digital engineering elements application in innovation and optimization of production flows", APVV-19-0418 "Intelligent solutions to enhance business innovation capability in the process of transforming them into smart businesses", VEGA 1/0438/20 "Interaction of digital technologies to support software and hardware communication of the advanced production system platform”, KEGA 001TUKE-4/2020 "Modernizing Industrial Engineering education to Develop Existing Training Program Skills in a Specialized Laboratory", VEGA 1/0340/21 "The impact of a pandemic and the subsequent economic crisis on the development of digitization of enterprises and society in Slovakia" and KEGA 009TUKE-4/2020 "Transfer of Digitization into Education in the Study Program Business Management and Economics".

\section{REFERENCES}

1. BALLAL P., GIORDANO V., DANG P., GORTHI S., MIRELES J., LEWIS F.: A LabVIEW based test-bed with off-the-shelf components for research in mobile sensor networks, Computer Aided Control System Design 2006 IEEE International Conference on Control Applications 2006 IEEE International Symposium on Intelligent Control 2006 IEEE, pp. 112-118, 2006.

2. WITKOWSKI K., SANIUK S.: Aspekt logistyczny zarzadzania infrastruktura komunalna miasta, Logistyka 41(2): 589-600, 2011.

3. ABDO J., GEORGANAS N.D., MOUFTAH H.: Test-Bed for Sensor Network Management Protocols, Communications 2006 23rd Biennial Symposium on, pp. 312-315, 2006.

4. STRAKA M., LENORT R., KHOURI S., FELIKS J.: Design of large-scale logistics systems using computer simulation hierarchic structure, International Journal of Simulation Modelling, 17(2018)1, 105-118. 
5. EDL M., LERHER T., ROSI B.: Energy efficiency model for the mini-load automated storage and retrieval systems. International Journal of Advanced Manufacturing Technology, (2013), 1-19. ISSN: 0268-3768.

6. PEKARCIKOVA M., TREBUNA P., MARKOVIC J.: Case study of modelling the logistics chain in production, 6th Conference on Modelling of Mechanical and Mechatronic Systems - MaMS: Modelling of mechanical and mechatronic systems, Book Series: Procedia Engineering, 96(2014), 355-361, Vysoke Tatry, Slovakia.

7. STRAKA M., KHAORI S., ROSOVA A., CAGANOVA D., CULKOVA K.: Utilization of computer simulation for waste separation design as a logistics system, International Journal of Simulation Modelling, 17(2018)4, 583-596.

8. ROSOVA A.: Methods and approaches to the evaluation of company performance: Poprad Economic And Management Forum 2017, 31-36, ISBN:97880-561-0519-1. 
